\title{
The first record of Brentidae (Coleoptera) in Eocene Rovno amber with description of a new fossil species of Toxorhynchus Scudder, 1893
}

\author{
Andris Bukejs ${ }^{1}$ and Andrei A. Legalov ${ }^{2,3}$ \\ ${ }^{1}$ Institute of Life Sciences and Technologies, Daugavpils University, Vienības 13, Daugavpils, 5401, Latvia \\ ${ }^{2}$ Institute of Systematics and Ecology of Animals, Siberian Branch, Russian Academy of Sciences, Frunze Street 11 , \\ Novosibirsk 630091, Russia \\ ${ }^{3}$ Altai State University, Lenina 61, Barnaul 656049, Russia
}

Correspondence: Andrei A. Legalov (fossilweevils@gmail.com)

Received: 14 May 2020 - Revised: 25 June 2020 - Accepted: 1 July 2020 - Published: 10 August 2020

\begin{abstract}
A new pear-shaped weevil, Toxorhynchus europeoeocenicus Bukejs et Legalov, sp. nov. (Coleoptera: Brentidae: Apioninae), is described from upper Eocene Rovno amber using X-ray microcomputed tomography $(\mu \mathrm{CT})$. The new fossil species differs from the extinct Toxorhynchus robustus Poinar et Legalov, 2015 (Dominican amber, lower Miocene) in the larger body size, narrower elytral striae, and wider pronotum. It is the first record of the family Brentidae in Rovno amber and the first record of the genus Toxorhynchus in the eastern hemisphere (urn:lsid:zoobank.org:pub:8FB7B299EE75-4556-B4EA-203A3CBED84C).
\end{abstract}

\section{Introduction}

The curculionoid beetles of amber were studied in detail among the Eocene faunas (Legalov, 2020). The largest numbers of new finds were described from Baltic amber (Legalov, 2020). The Rovno amber fauna was studied less intensely. As a result of research of the new materials collected during the last years, 16 species from four families were described (Gratshev and Perkovsky, 2008; Petrov and Perkovsky, 2008, 2018; Nazarenko and Perkovsky, 2009, 2016; Nazarenko et al., 2011; Legalov et al., 2018, 2019; Bukejs and Legalov, 2019a, b). However, some groups known from Baltic amber, e.g. Nemonychidae; Anthribidae: Allandrini, Belidae, Brentidae; Rhynchitidae: Sayrevilleini, Rhynchitini; Curculionidae: Cryptorhynchini, Eugnomini, Rhamphini, etc., have so far not been found in Rovno amber (Alekseev, 2017; Legalov, 2020; Bukejs et al., 2020). The representatives of these groups can be expected in new amber samples. In examined Rovno amber material, a new species belonging to the genus Toxorhynchus of the subfamily Apioninae was discovered and is described here. It is the first record of the family Brentidae in this fossil resin and the first record of the genus Toxorhynchus in the eastern hemisphere.

\section{Material and methods}

The material examined is deposited in the collection of the Museum of Amber Inclusions, University of Gdańsk (Poland) [MAIG]. The amber piece was polished by hand, allowing improved views of the included specimen, and was not subjected to any supplemental fixation.

The X-ray micro-CT observations of specimen "6684" [MAIG] were conducted at Daugavpils University, Daugavpils, Latvia (DU), using a Zeiss Xradia 510 Versa system. Scans were performed with a polychromatic X-ray beam at an energy of $40 \mathrm{kV}$ and power of $3 \mathrm{~W}$. Sample-to-detector distance was set to $17.5 \mathrm{~mm}$, and source-to-sample distance was $47.7 \mathrm{~mm}$. Tomographic slices were generated from 3001 rotational steps through a $360^{\circ}$ rotation, using a $4 \times$ objective, and the exposure time during each projection was set to $5 \mathrm{~s}$. Acquired images were binned $(2 \times 2 \times 2)$ giving a voxel size of $4.87 \mu \mathrm{m}$. Images were imported into the Dragonfly PRO (ver. 4.1) software platform for interactive segmentation and $3 \mathrm{D}$ visualization. 
Observations of the specimens were made using a Nikon $\mathrm{SMZ}^{\circledR} 745 \mathrm{~T}$ stereomicroscope. The photographs were taken using a Canon $70 D^{\circledR}$ camera with a macro lens (Canon MP-E $65 \mathrm{~mm}$ ). Extended depth of field at high magnifications was achieved by combining multiple images from a range of focal planes using Helicon Focus ${ }^{\circledR}$ v. 6.0.18 software.

The morphological terminology used in this paper follows Alonso-Zarazaga (1990) and Lawrence et al. (2010).

\section{Systematic paleontology}

Family Brentidae Billberg, 1820

Subfamily Apioninae Schoenherr, 1823

Tribe Apionini Schoenherr, 1823

Subtribe Toxorhynchina Scudder, 1893

Genus Toxorhynchus Scudder, 1893

Toxorhynchus europeoeocenicus sp. nov. urn:1sid:zoobank.org:act:6A774735-C381-4B6B8F9B-C5999C815FEB

Figs. 1-4

\section{Etymology}

The specific name is a compound word and combines "Europe" (Europe, where the Rovno amber originates) and "Eocene" (the time of the origin of this species).

\section{Type material}

Holotype. 6684 [MAIG] (ex. coll. Jonas Damzen JDC 8542); adult, male. Rather complete beetle (apical metatarsomeres missing) is included in a yellow, transparent amber piece, with dimensions of $68 \mathrm{~mm} \times 33 \mathrm{~mm}$ and a maximum thickness of $14 \mathrm{~mm}$. Syninclusions consist of one damaged specimen of Araneae and few small gas vesicles.

\section{Type stratum}

Rovno amber, upper Eocene.

\section{Type locality}

Rivne Oblast (region), Ukraine.

\section{Description}

Measurements. Body length (without rostrum) $1.9 \mathrm{~mm}$; rostrum length $0.54 \mathrm{~mm}$; pronotal length $0.4 \mathrm{~mm}$, pronotum maximum width $0.5 \mathrm{~mm}$; elytral length $1.4 \mathrm{~mm}$, elytral maximum width about $1.0 \mathrm{~mm}$
Body. Widely ovoid, strongly convex; dark brown with rostrum, antennae, and legs rufous; with sparse, short, and recumbent setae dorsally (elytra without coarser, denser, and paler scales basally and without postscutellar spot of denser scales).

Head. Short, $0.4 \times$ as long as rostrum length; widened behind eyes; densely covered with rather large punctures, distance between punctures less than diameter of one puncture, interspaces convex. Rostrum distinctly curved, cylindrical, subparallel-sided, slightly widened medially; sparsely covered with fine punctures; about $4 \times$ as long as wide basally and medially, $4.9 \times$ as long as wide apically, and $1.5 \times$ as long as pronotum length; without preocular sulci laterally. Place of antennal insertion not dilated. Antennal scrobes deep. Temples slightly convex, moderately large, about $0.8 \times$ as long as eye transverse diameter. Compound eyes rather large, oval, moderately convex, with large facets, about $1.4 \times$ as long as wide. Forehead slightly convex, slightly wider than rostrum base width, with dense micropunctation, without large punctures medially. Gular suture single.

Antennae. Straight, with 11 antennomeres, clavate, with distinct three-segmented club, rather short, reaching anterior one-third of pronotum, sparsely covered with fine setae, inserted ventrally in basal one-third of rostrum, at distance of forehead greater than width of forehead; scape subcylindrical, short, not extending to eyes, slightly dilated apically, about $3.1 \times$ as long as wide, about $0.21 \times$ as long as rostrum; flagellomeres distinctly widened apically; antennomeres $2-4$ elongate to slightly elongate, $0.5-0.7 \times$ as wide as long; antennomeres 5-7 subquadrate; antennomere 8 transverse, $1.3 \times$ as wide as long; club compact, about $0.5 \times$ as long as flagellum; antennomere 9 trapezoidal, dilated apically, slightly transverse, $1.2 \times$ as wide as long, and $1.5 \times$ as wide as antennomere 8 ; antennomere 10 slightly narrowed apically, transverse, $1.5 \times$ as wide as long; antennomere 11 conical, with pointed apex, nearly as long as wide; relative length ratios of antennomeres $1-11$ equal to $31: 19: 13: 11: 9: 8: 9: 9: 15: 12: 14$. Sutures of club distinct.

Prothorax. Pronotum nearly campaniform, widest medially, slightly convex, transverse, $1.2 \times$ as wide as long, narrower than anterior elytral margin, distinctly narrowed anteriad, with weak basal flange; anterior margin almost straight, posterior margin bisinuated; densely covered with coarse punctation, distance between punctures equal to $0.5-1.2 \times$ diameter of one puncture (discal punctation slightly sparser), interspaces between punctures slightly convex, finely punctate. Pronotal vestiture apparently centripetal. Prosternum without postorbital lobes; densely covered with small punctures, interspaces between punctures convex; pre- and postcoxal portions of prosternum short, $0.3 \times$ and $0.4 \times$ respectively as long as diameter of procoxa. Procoxal cavities contiguous.

Pterothorax. Sutellum small, suboval, $1.1 \times$ as long as wide, anterior margin slightly concave, apex widely rounded. 

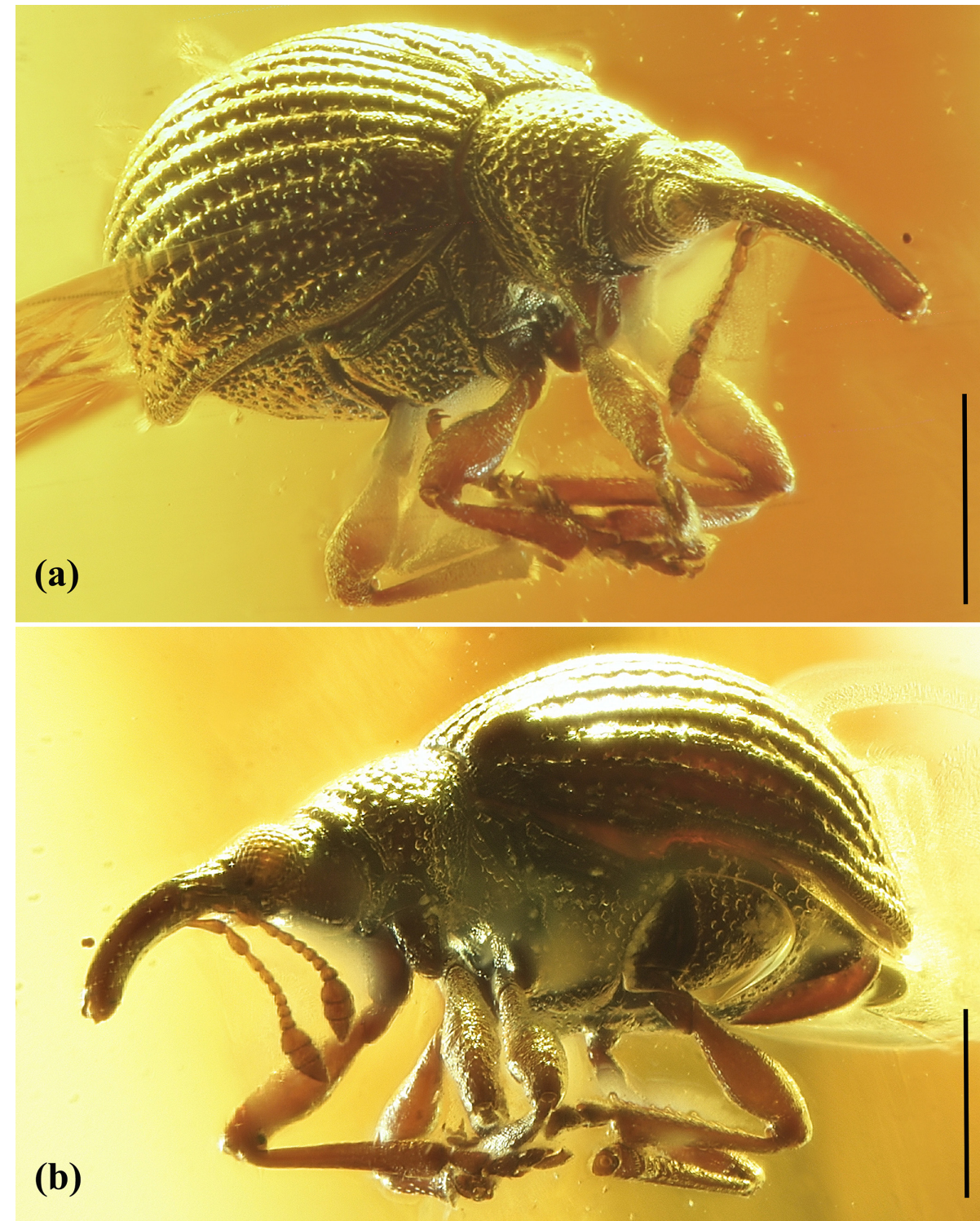

Figure 1. Photomicrographs of Toxorhynchus europeoeocenicus sp. nov., holotype, 6684 [MAIG], habitus: (a) fronto-lateral view; (b) left lateral view. Scale bars $=0.5 \mathrm{~mm}$.

Elytra widely ovoid, convex, $1.3 \times$ as long as maximum wide, $3.8 \times$ as long as pronotum, punctatostriate; humeral calli developed, protruding; anterior margin concave medially, lateral margins subparallel in anterior half, slightly convex medially, and narrowed at apex. Elytral base wider than pronotum, without crenulate or granulate carina. Elytral punctures small, deep, and rather dense, arranged in nine regular striae, distance between strial punctures equal to $1.3-3.1 \times$ diameter of puncture (punctation sparser in posterior portion), striae distinct throughout entire length of elytra; elytral stria 10 lacking; intervals strongly convex, covered with secondary micropunctation, distance between striae about $3 \times$ diameter of puncture; hairs not condensed on base of elytral interval 3; sutural stria lacking. Meso- and metaventrites densely covered with rather large punctures (as pronotal punctation), distance between punctures less than diameter of one puncture, interspaces between punctures convex. Disc of metaventrite convex, without median tubercle. Metepisternum wide, $3.5 \times$ as long as maximum width, with longitudinal row of large punctures medially; lateral margins slightly concave, anterior and posterior margins oblique.

Legs. Long, rather slender, sparsely covered with fine punctures. Procoxae conical, as long as wide; mesocoxae subconical, slightly transverse, $1.2 \times$ as wide as long, narrowly separated by $0.2 \times$ transverse diameter of mesocoxa; metacoxae oval, transverse, about $1.9 \times$ as wide as long, widely separated by about $0.5 \times$ transverse diameter of meta- 

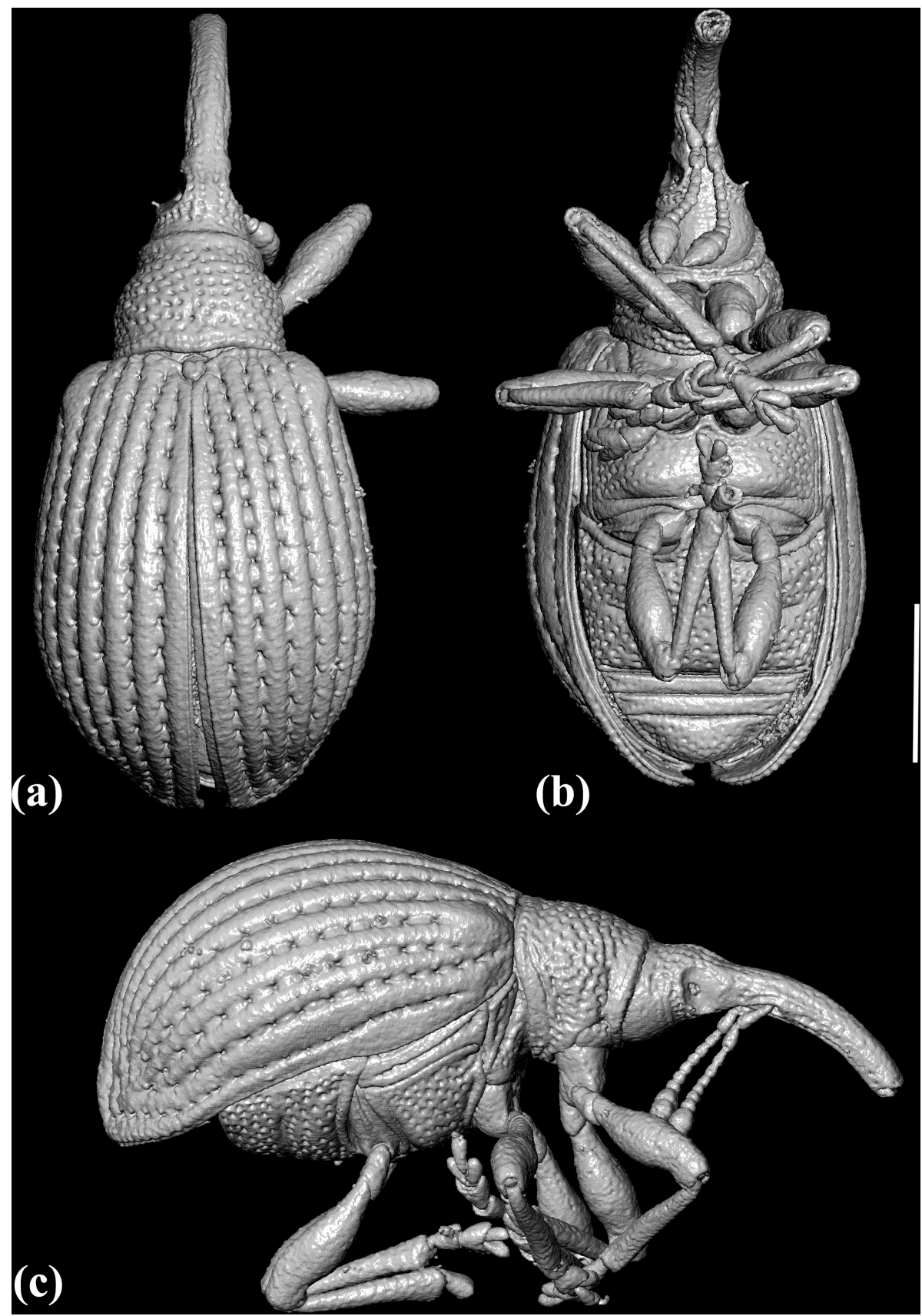

Figure 2. X-ray micro-CT renderings of Toxorhynchus europeoeocenicus sp. nov., holotype, 6684 [MAIG], habitus: (a) dorsal view; (b) ventral view; (c) right lateral view. Scale bar $=0.5 \mathrm{~mm}$.

coxa. Trochanters elongate. Femora clavate, slightly swollen, not meeting coxae, without ventral denticle. Tibiae slightly flattened and curved, dilated in apical portion. Tarsi moderately long (protarsus $0.6 \times$ as long as protibia), pelma developed; tarsomeres $1-3$ of all legs dilated; protarsomere 1 trapezoidal, dilated apically, slightly elongate, $1.1 \times$ as long as wide, protarsomere 2 trapezoidal, strongly dilated apically, elongate, $1.3 \times$ as long as wide, protarsomere 3 deeply bilobed, strongly dilated apically, transverse, $0.8 \times$ as long as wide, ultimate protarsomere elongate, projecting from protarsomere 3 to about half of its length, relative length ratios of protarsomeres $1-4$ equal to $11: 11: 10: 11$ (laterally). Tarsal claws rather large, free, and apparently with basal denticle.

Abdomen. With five visible ventrites, densely covered with moderately large punctures (as metasternal punctation); ventrites 1-2 fused, longest, equal in length, strongly convex, elevated; ventrites 3-4 short, equal in length, almost flat, orientated in different plane to ventrites $1-2$, ventrite 3 about $0.4 \times$ 


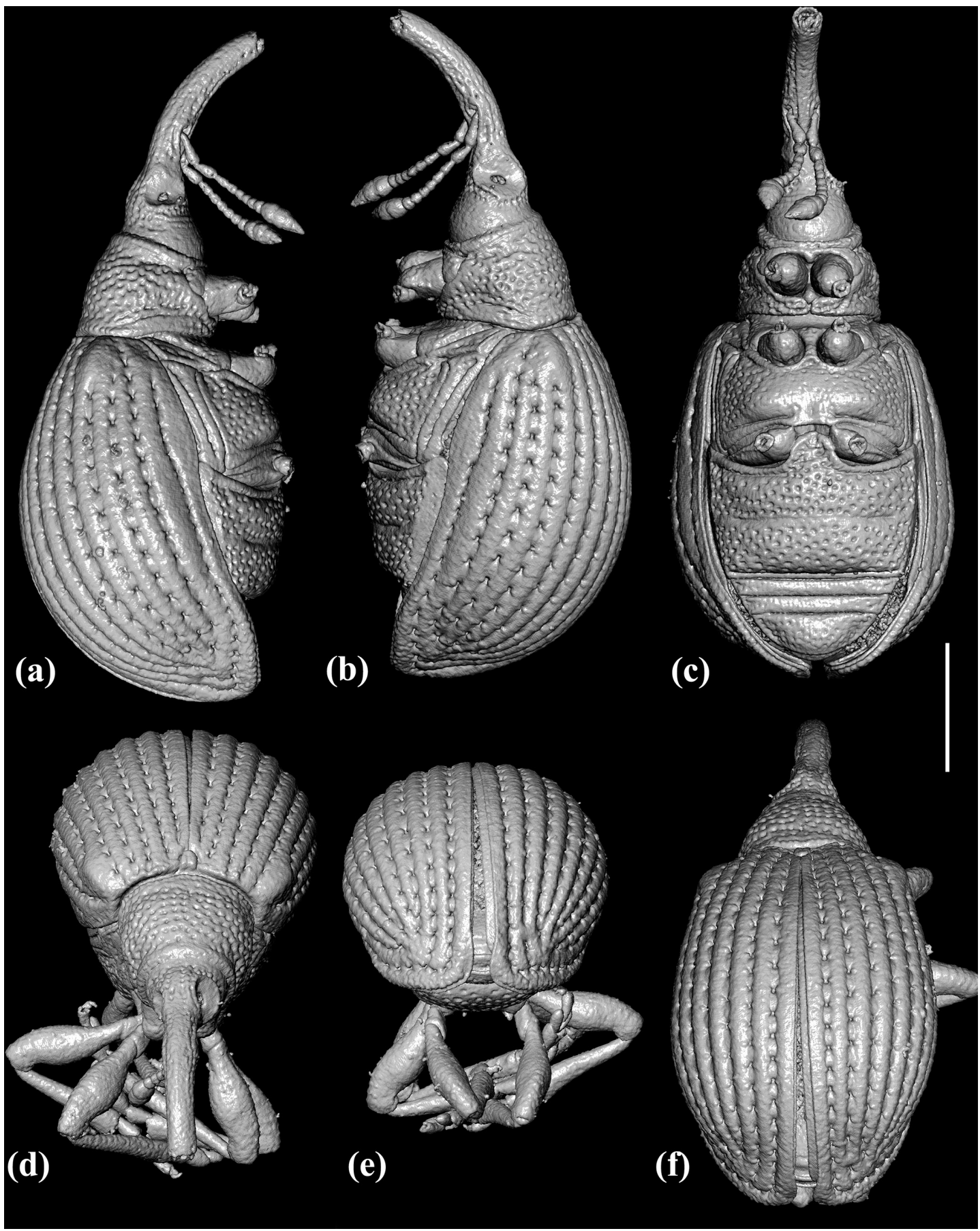

Figure 3. X-ray micro-CT renderings of Toxorhynchus europeoeocenicus sp. nov., holotype, 6684 [MAIG], habitus: (a) right lateral view, without legs; (b) left lateral view, without legs; (c) ventral view, without legs; (d) frontal view; (e) caudal view; (f) dorso-caudal view. Scale bar $=0.5 \mathrm{~mm}$.

as long as ventrite 2 ; ventrite 5 slightly convex, with widely rounded apex; abdominal suture between ventrites 1 and 2 straight, fine, distinct almost throughout length, abdominal sutures between ventrites 2 and 5 straight, sharp, and deep, distinct throughout length; intercoxal process of ventrite 1 wide, about $0.7 \times$ as wide as transverse diameter of meta- coxal; relative length ratios of abdominal ventrites $1-5$ equal to $8: 8: 3: 3: 6$ (medially, without intercoxal process).

Aedeagus. Median lobe narrow, with narrowly rounded apex; curved in lateral view; apparently with longitudinal, medial furrow ventrally (Fig. 4). 


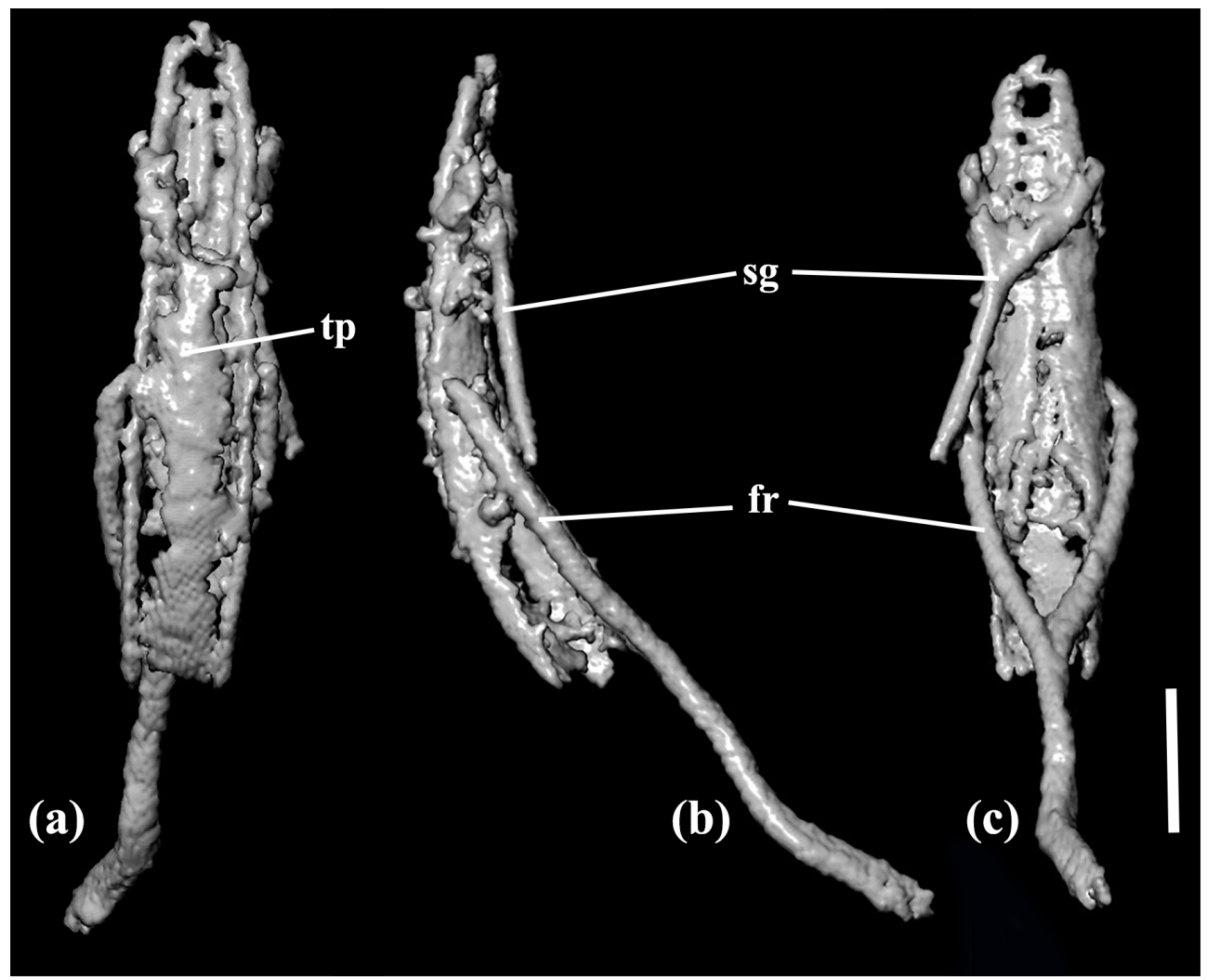

Figure 4. X-ray micro-CT renderings of Toxorhynchus europeoeocenicus sp. nov., holotype, 6684 [MAIG], aedeagus: (a) dorsal view; (b) lateral view; (c) ventral view. Scale bar $=0.1 \mathrm{~mm}$. Abbreviations: fr - free ring; tp - tegminal plate; sg - spiculum gastrale.

Tegmen. Tegminal plate apically distinctly notched (Fig. 4a). Parameres fused to basal piece.

\section{Comparison}

Toxorhynchus europeoeocenicus sp. nov. is similar to T. robustus Poinar et Legalov, 2015 from Dominican amber in body shape but differs in the larger body size, narrower elytral striae, and wider pronotum.

\section{Remark}

The studied amber beetle shows the combination of characters corresponding to the family Brentidae: gular suture single, antennae straight, abdominal ventrites 1-2 fused and elongate, ventrites 3-4 shortened, ventrites 1-2 and ventrites 3-5 oriented in different planes. The contiguous procoxal cavities, femora not meeting coxae, elongate trochanters, deep antennal scrobes, scape short, not extending to eyes, visible scutellum, and base of elytra without crenulate or granulate carina suggest placement in the subfamily Apioninae. Placement of this specimen in the tribe Apionini is defined on the elytral stria 10 absent, separated mesocoxae, distinct sutures of antennal club, pronotal vestiture centripetal, rostrum laterally lacking preocular sulci, head widened behind eyes, place of antennal insertion not di- lated, antennae inserted in basal one-third of the rostrum, tarsomere 2 slightly longer than wide, and hairs not condensed on the base of the elytral interval 3. The new species belongs to the subtribe Toxorhynchina based on the campaniform pronotum, curved rostrum, elytral base wider than pronotum, tegminal plate apically distinctly notched, and parameres fused to basal piece. The male metaventrite is not tuberculate, and antennae are inserted in basal one-third of the rostrum. This indicates that a new species belongs to the genus Toxorhynchus. This new fossil species is assigned to the Toxorhynchus decoloratum group based on the combination of the following characters: pronotum with weak basal flange, male legs simple, forehead slightly wider than rostrum base width, antennae inserted at distance of forehead greater than width of forehead, elytra without coarser, denser, and paler scales basally and without postscutellar spot of denser scales.

\section{Discussion}

The family Brentidae is a very diverse group (Legalov, 2018a). The earliest Brentidae belong to the subfamily Eurhynchinae which is known from the Aptian-Albian of Brazil (Zherikhin and Gratshev, 2004). The most ancient Apioninae were described from the Turonian of Kazakhstan (Kzyl- 


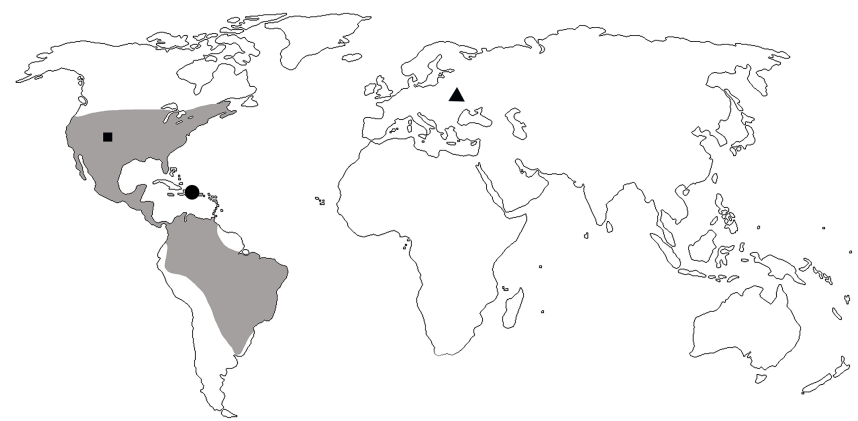

Figure 5. Distribution of the genus Toxorhynchus with extant (shaded area) and fossil records: records from Florissant Formation, Colorado, USA (black square); records from Dominican amber (black dot); and T. europeoeocenicus sp. nov. from Rovno amber (black triangle).

Dzhar) (Legalov, 2014). Representatives of this subfamily are also known from the Paleocene of the south of the Russian Far East (Legalov, 2015) and France (Legalov et al., 2017), Eocene Oise amber (Kirejtshuk et al., 2015) and Baltic amber (Legalov, 2015; Legalov and Bukejs, 2015), Middle Eocene of Roan Mountain (Scudder, 1893) and Green River (Legalov, 2018b), Upper Eocene of Florissant (Scudder, 1893, Legalov, 2013, 2015), etc. The richest apionine fauna is described from the lower Miocene Dominican amber (Poinar Jr. and Legalov, 2015).

The genus Toxorhynchus was first described from the Florissant Formation, Eocene of the USA (Scudder, 1893). In the recent fauna, it was described as Coelocephalapion Wagner, 1914. Synonymy was established by Legalov (2013). This genus is widely distributed in North and South America: Canada, the USA, Mexico, Belize, Guatemala, El Salvador, Honduras, Nicaragua, Costa Rica, Panama, Colombia, Venezuela, Trinidad, Brazil, Bolivia, Argentina, and the West Indies (Kissinger, 1968, 1974, 1992, 1999; de Sousa et al., 1999). Fourteen species were described from lower Miocene Dominican amber, and six of them belong to the Toxorhynchus decoloratum group. The schematic distribution of Toxorhynchus including fossil records is mapped in Fig. 5. Toxorhynchus europeoeocenicus sp. nov. from Eocene Rovno amber is the first record of the genus in the eastern hemisphere.

The similarities between Eocene Baltic amber and recent North and South American Curculionoidea have been documented (Zherikhin, 1971; Legalov, 2016, 2020; Alekseev, 2017). The relationship between Rovno amber and recent North and South American faunas consisted in the discovery of few fossil species (Bukejs and Legalov, 2019a; Legalov et al., 2019) belonging to the tribes Anypotactini and Naupactini which are distributed mainly in Central and South America (Alonso-Zarazaga and Lyal, 1999). The record of the representative of this genus shows that common groups even at the generic level were present in the American and European faunas in the Eocene.

Data availability. All material included in the paper is deposited in the collection of the Museum of Amber Inclusions, University of Gdańsk (Poland) [MAIG], and all data are included in the description. X-ray microtomography volume renderings of the habitus (Bukejs, 2020a), habitus (without legs, Bukejs, 2020b), and aedeagus (Bukejs, 2020c) of Toxorhynchus europeoeocenicus sp. nov., holotype, 6684 [MAIG] are available as a Video Supplement.

Video supplement. Volume renderings of X-ray microtomography of the habitus, habitus (without legs), and aedeagus of Toxorhynchus europeoeocenicus sp. nov., holotype, 6684 [MAIG]. The videos are available at

- https://doi.org/10.5446/46732 (Bukejs, 2020a),

- https://doi.org/10.5446/46733 (Bukejs, 2020b),

- https://doi.org/10.5446/46788 (Bukejs, 2020c).

Author contributions. $\mathrm{AB}$ and AAL designed the study, drafted the manuscript, and contributed to the writing and discussion. AAL performed systematic placement of this fossil specimen.

Competing interests. The authors declare that they have no conflict of interest.

Acknowledgements. The authors are sincerely grateful to Elżbieta Sontag (Museum of Amber Inclusions, University of Gdańsk, Poland) for the loan of the interesting fossil specimen, to Kristaps Kairišs (Daugavpils University, Daugavpils, Latvia) for assistance in X-ray microcomputed tomography, and to Jonas Damzen (Vilnius, Lithuania) for assistance during our amber research and permission to use photographs of the holotype. We thank Vitalii I. Alekseev (Kaliningrad Regional Amber Museum, Kaliningrad, Russia) and Alexander G. Kirejtshuk (Zoological Institute, Russian Academy of Sciences, St. Petersburg, Russia) for valuable suggestions that improved the manuscript.

Review statement. This paper was edited by Florian Witzmann and reviewed by Vitalii Alekseev and Alexander Kirejtshuk.

\section{References}

Alekseev, V. I.: Coleoptera from the middle-upper Eocene European ambers: Generic composition, zoogeography and climatic implications, Zootaxa, 4290, 401-443, https://doi.org/10.11646/zootaxa.4290.3.1, 2017.

Alonso-Zarazaga, M. A.: Revision of the supraspecific taxa in the Palaearctic Apionidae Schoenherr, 1823 (Coleoptera, Cur- 
culionoidea). 2. Subfamily Apioninae Schoenherr, 1823: Introduction, keys and descriptions, Graellsia, 46, 19-156, 1990.

Alonso-Zarazaga, M. A. and Lyal, C. H. C.: A world catalogue of families and genera of Curculionoidea (Insecta: Coleoptera), Entomopraxis, Barcelona, Spain, 315 pp., 1999.

Billberg, G. J.: Enumeratio Insectorum in Musaeo Gust. Joh. Bill berg. Typis Gadelianis, Stockholm, 138 pp., 1820.

Bukejs, A.: Toxorhynchus europeoeocenicus Bukejs et Legalov sp. nov., holotype, 6684 [MAIG], X-ray micro-CT volume rendering of the habitus, TIB, https://doi.org/10.5446/46732, 2020a.

Bukejs, A.: Toxorhynchus europeoeocenicus Bukejs et Legalov sp. nov., holotype, 6684 [MAIG], X-ray micro-CT volume rendering of the habitus (without legs), TIB, https://doi.org/10.5446/46733, 2020 b.

Bukejs, A.: Toxorhynchus europeoeocenicus Bukejs et Legalov sp. nov., holotype, 6684 [MAIG], X-ray micro-CT volume rendering of the aedeagus, TIB, https://doi.org/10.5446/46788, 2020c.

Bukejs, A. and Legalov, A. A.: First record of the tribe Naupactini (Coleoptera: Curculionidae) in Rovno amber, Foss. Rec., 22, 2530, https://doi.org/10.5194/fr-22-25-2019, 2019.

Bukejs, A. and Legalov, A. A.: The first record of Rhynchitidae (Coleoptera) from Rovno amber, Entomol. Fennica, 30, 168172, https://doi.org/10.33338/ef.87173, 2019b.

Bukejs, A., Háva, J., and Alekseev, V. I.: A new fossil species of Attagenus Latreille (Coleoptera: Dermestidae) in Rovno and Baltic ambers, with a brief review of known fossil beetles from the Rovno amber Lagerstätte, Foss. Rec., 23, 95-104, https://doi.org/10.5194/fr-23-95-2020, 2020.

de Sousa, V. O., Ribeiro-Costa, C. S., and Rosado-Neto, G. H.: A preliminary overview of the Brazilian Apioninae (Coleoptera: Brentidae) with an illustrated key for genera, and a checklist with distribution information, Biota Neotrop., 19, e20190813, https://doi.org/10.1590/1676-0611-bn-2019-0813, 2019.

Gratshev, V. G. and Perkovsky, E. E.: New species of the genus Glaesotropis (Insecta: Coleoptera: Anthribidae) from Rovno amber, Paleontol. J., 42, 60-63, 2008.

Kirejtshuk, A. G., Legalov, A. A., and Nel, A.: A new genus of the subfamily Apioninae (Coleoptera: Brentidae) from the lowermost Eocene Oise amber, Paleontol. J., 49, 1436-1441, https://doi.org/10.1134/S0031030115130055, 2015.

Kissinger, D. G.: Curculionidae subfamily Apioninae of North and Central America, South Lancaster, MA, Taxonomic Publications, 559 pp., 1968.

Kissinger, D. G.: Apioninae occuring in the West Indies (Curculionidae, Coleoptera), Riverside, CA, Taxonomic Publications, 57 pp., 1974.

Kissinger, D. G.: Apionidae from North and Central America. Part 4. Generic classification and introduction to the genus Coelocephalapion Wagner, with new species from Mexico and Venezuela (Coleoptera), Insecta Mundi, 6, 65-77, 1992.

Kissinger, D. G.: Apionidae from North and Central America. Part 6. Description of new species of Apionion Kissinger, Coelocephalapion Wagner and Trichapion Wagner (Coleoptera), Insecta Mundi, 13, 21-37, 1999.

Lawrence, J. F., Beutel, R. G., Leschen, R. A. B., and Ślipiński, S. A.: Chapter 2. Glossary of Morphological Terms, in: Handbook of Zoology, Arthropoda: Insecta, Tb. 40, Coleoptera (Beetles), Vol. 2, Morphology and Systematics (Elateroidea,
Bostrichformia, Cucujiformia partim), Berlin, New York, Walterde Gruyter, 9-20, 2010.

Legalov, A. A.: New and little known weevils (Coleoptera: Curculionoidea) from the Paleogene and Neogene, Hist. Biol., 25, 59-80, https://doi.org/10.1080/08912963.2012.692681, 2013.

Legalov, A. A.: New Nemonychidae, Brentidae and Curculionidae (Coleoptera: Curculionoidea) from the Turonian of Kzyl-Dzhar (Kazakhstan), Hist. Biol., 26, 675-689, https://doi.org/10.1080/08912963.2013.829826, 2014.

Legalov, A. A.: Fossil weevils (Coleoptera, Obrienioidea, Curculionoidea) from Mesozoic and Cainozoic, Paleontol. J., 49, 1442-1513, https://doi.org/10.1134/S0031030115130067, 2015.

Legalov, A. A.: Two new genera and four new species of fossil weevils (Coleoptera: Curculionoidea) in Baltic amber, Entomol. Fennica, 27, 57-69, https://doi.org/10.33338/ef.59124, 2016.

Legalov, A. A.: Annotated key to weevils of the world. Part 1. Families Nemonychidae, Anthribidae, Belidae, Ithyceridae, Rhynchitidae, Brachyceridae and Brentidae, Ukrainian J. Ecology, 8, 780-831, https://doi.org/10.15421/2018_280, 2018a.

Legalov, A. A.: New weevils (Coleoptera, Curculionoidea) from the Eocene of the Green River, United States: Part 1, Paleontol. J., 52, 294-302, https://doi.org/10.1134/S0031030118030061, 2018 b.

Legalov, A. A.: A review of the Curculionoidea (Coleoptera) from European Eocene ambers, Geosciences, 10, 1-74, https://doi.org/10.3390/geosciences10010016, 2020.

Legalov, A. A. and Bukejs, A.: Succinapion telnovi n. gen. et n. sp. of the tribe Kalcapiini (Coleoptera: Brentidae: Apioninae) in Baltic amber, Hist. Biol., 26, 603-607, https://doi.org/10.1080/08912963.2013.809526, 2015.

Legalov, A. A., Nazarenko, V. Y., and Perkovsky, E. E.: A new genus of fungus weevils (Coleoptera: Anthribidae) in Rovno amber, Foss. Rec., 21, 207-212, https://doi.org/10.5194/fr-21-2072018, 2018.

Legalov, A. A., Nazarenko, V. Y., and Perkovsky, E. E.: New weevils (Coleoptera: Curculionidae) from the Rovno amber, Paleontol. J., 53, 1045-1059, https://doi.org/10.1134/S0031030119100101, 2019.

Legalov, A. A., Nel, A., and Kirejtshuk, A. G.: New and little known weevils (Coleoptera: Curculionoidea) from the $\mathrm{Pa}-$ leocene of Menat (France), C. R. Palevol., 16, 248-256, https://doi.org/10.1016/j.crpv.2016.10.007, 2017.

Nazarenko, V. Y. and Perkovsky, E. E.: A new genus and species of Dryophthorid weevils (Coleoptera, Dryophthoridae: Stromboscerinae) from the Rovno amber, Paleontol. J., 43, 1097-1100, https://doi.org/10.1134/S003103010909010X, 2009.

Nazarenko, V. Y. and Perkovsky, E. E.: A new species of Derelomine weevils (Coleoptera, Curculionidae, Curculioninae: Acalyptini) from the Rovno amber, Paleontol. J., 50, 991-996, https://doi.org/10.1134/S0031030116090094, 2016.

Nazarenko, V. Y., Legalov, A. A., and Perkovsky, E. E.: A new species of the genus Caulophilus Woll. (Coleoptera: Curculionidae: Cossoninae) from the Rovno amber, Paleontol. J., 45, 287 290, https://doi.org/10.1134/S0031030111030105, 2011.

Petrov, A. V. and Perkovsky, E. E.: New species of bark beetles from the Rovno amber (Insecta: Coleoptera: Scolytidae), Paleontol. J., 42, 406-408, https://doi.org/10.1134/s0031030108040096, 2008 . 
Petrov, A. V. and Perkovsky, E. E.: A new genus and species of Scolytinae (Coleoptera: Curculionidae) from the Rovno amber, Paleontol. J., 52, 164-167, https://doi.org/10.1134/S0031030118020090, 2018.

Poinar Jr., G. O. and Legalov A. A.: New Apioninae (Coleoptera: Brentidae) in Dominican amber, Hist. Biol., 27, 134-157, https://doi.org/10.1080/08912963.2013.871010, 2015.

Schoenherr, C. J.: Curculionides [Tabula synoptica familiae Curculionidum], Isis von Oken, 1823, 1132-1146, 1823.

Scudder, S. H.: Tertiary Rhynchophorus Coleoptera of the United States, Monogr. US Geol. Surv., 21, 1-206, 1893.
Wagner, H.: Beitrag zur Kenntnis der Apion-Fauna Zentral- und Süd- Amerikas. Beschreibungen neuer Arten, m. Theil., Archiv fur Naturgeschichte, A, 9, 137-164, 1914.

Zherikhin, V. V.: O dolgonosikach (Insecta, Coleoptera) baltiyskogo jantarja [On the weevils (Insecta, Coleoptera) from the Baltic amber], Trudy Palaeontologicheskogo Instituta, 130, 197-209, 1971.

Zherikhin, V. V. and Gratshev, V. G.: Fossil weevil beetles (Coleoptera, Curculionoidea) from the Lower Cretaceous of northeastern Brazil, Paleontol. J., 38, 528-537, 2004. 